\title{
It's Getting Personal: Personalisation of political campaigns in four Prague districts during the 2018 Czech Senate elections $^{1}$
}

\author{
OLGA BRUNNEROVÁ
}

\section{Sciendo}

Politics in Central Europe (ISSN: 1801-3422)

Vol. 15, No. 2

DOI: $10.2478 /$ pce-2019-0018

\begin{abstract}
In October 2018 Senate elections were held in the Czech Republic. In the capital city of Prague, 41 candidates - both party members and independents - contested for the votes of the electorate of four districts. The goal of this article is to analyse the electoral campaigns which were conducted within these four districts in the online sphere of the social media site Facebook. Through complementary quantitative and qualitative methods, this text focuses its attention on the communication of the candidates themselves, but also on the reactions of the electorate in the environment of social media. Employing qualitative content analysis of the topics addressed by the candidates, sentiment analysis of user commentaries and quantitative analysis of posting frequency and followership, this article examines whether the candidates who led an active personalised campaign were more successful than the candidates who communicated with the public only sporadically and with less personalisation. The aim is to explore how the campaigns of successful candidates were conducted and to accentuate that social media is becoming more important in the campaigns of individual candidates, but that they are not a panacea for non-partisan candidates without an established supporter base and financial resources.
\end{abstract}

Keywords: Political communication, Senate elections, social media, Facebook, the Czech Republic

1 This paper was written as a part of a research project „Politická komunikace na sociálních sítích: analýza politické komunikace na případu voleb do Senátu 2018 v pražských volebních obvodech (č. E22-66)” financed from the Internal Grant System of the Metropolitan University Prague. 
With the growth of social networks, political communication has undergone a significant change. The expansion of new media has created a new infrastructure for permanent political campaigning, and it allows political actors to create and share content directly with the electorate. Using the internet for political campaign purposes has become a key strategy of many political parties and individual candidates (see, e.g., Metz et al. 2019; Larsson 2015). It has always been crucial for political subjects to adopt new technologies to increase their chances of electoral success in the everchanging media environment. Incorporating the internet, and especially Web 2.0, allows candidates to reach an even larger number of voters faster and more effectively than previously possible with radio and television broadcasts (Towner - Duolio 2012). Especially in the past decade we can observe the incorporation of new media into the communication strategies in Western and Central Europe, as social media networks occupy an increasingly important role in the lives of the citizens and thus allow for more direct and interactive communication between citizens and politicians (Rainie a Smith 2012, Sweetser - Lariscy 2008, Quinlan et al. 2017: 1).

As the use of internet and especially Web 2.0 is seeping through from the established democracies of western Europe and the US, and the social networks are becoming a more prominent feature in everyday political communication in the countries of Central Europe as well as in the Czech Republic itself, political actors are even more encouraged to regularly address the electorate directly via the internet. By sharing their posts, updating information on Facebook or Twitter, publishing videos on YouTube or pictures on Instagram, political candidates can continuously speak to the public without the filters and editorialising influence of the mainstream media. Especially in second-order elections - and particularly in the elections to a body that is often considered by the public as inefficient or even redundant, such as the Senate of the Parliament of the Czech Republic (see, e.g. ČT24 2018) - reaching out to the electorate and keeping it engaged may prove to be crucial. Employing the internet in political communication makes it possible to surpass the need to organise frequent press releases and conferences and communicate the political program of the candidate to often politically disengaged - voters from the comfort of their homes, or to be precise, their computer or phone screens. All that the 41 candidates in Prague's four districts electing a senator needed to do was refresh their status on social media or post a short video to get their message out to the voters. Although campaign communication is not usually this simple, communicating directly through social media gave candidates the tools to coordinate volunteer activities, raise funds, increase the interactivity of the campaign and quickly disseminate information, opinions and PR materials beyond the scope of traditional media (see e.g. Ceccobelli 2018: 1, Aldrich et al. 2016, Chadwick - Stromer-Galley 2016, Grusell - Nord 2016, Blumler - Kavanagh 1999). 
However, the question remains to which degree these tools are used by local politicians and candidates, as well as political parties in the Czech Republic and the other countries of Central and Eastern Europe. Communicating with the electorate via the internet, implementing social media and using interactive webpages has become the de facto norm in the western world, where launching a site and establishing a social network presence is often one of the first steps after announcing or launching a new political subject (Vergeer - Franses 2015: 1, Dang-Xuan et al. 2013). However, political actors are still getting used to the idea of reaching out to citizens in the everchanging and informal environment of Web 2. 0. Especially in the time before the elections, but also in the in-between periods due to the permanent electoral campaign-style many parties choose nowadays, communicating in real-time on social media, sharing a wide range of media content, including pictures and videos, or even launching surveys and fundraisers, can give candidates a crucial advantage in the electoral race. It is important to explore how these tools are employed primarily by individual candidates who do not possess a more extensive bureaucratic apparatus, a stable voter base of political parties or significant party funds, as they present a unique opportunity to surpass the obstacles of mass media communication and personalize the communication with voters in real-time. Although we encounter extensive research into political communication taking place online in political science research, the focus on the Czech Republic and especially on campaigns run by individual politicians is not as prominent and focuses rather on the aspects of participation or representation rather than on the what the candidates are sharing with the users and their reaction (see Hrdina 2013, Vochocová - Švelch 2015 or Vochocová - Štětka - Mazák 2015). Thus, the presented analysis provides a look into this form of self-presentation on social media, as well the feedback provided by the recipients of such communication, as it can be assumed that employing Web 2.0 in one form or another will only become more important for candidates, as well as for political parties in the future. Yet, as the following text shows, establishing quality and interactive political communication with the electorate is still not commonplace and natural for many candidates, even in elections, where individual candidates are in the centre of attention.

\section{Electoral campaigns on social media}

For scholars researching medial communication, electoral campaigns are among the most important sources (Ceccobelli 2018:30). The process of the personalisation of politics, as well as electoral campaigns, draws the attention of the scholarly public especially in the context of the voting and decision-making the process of the electorate (Cabada - Tomšič 2016: 1). There is no consensus on the importance of personalisation in elections where the voters are choosing 
parties with the leaders they prefer, or if they choose to sympathise with the leaders of the parties they already prefer (Belluci - Garzia - Lewis-Beck 2015). An increasing number of academic studies focuses on the topic of electoral campaigns that are conducted in the online environment and the unique characteristics of the way these are organised. As the internet is now used by more than 4 billion users across the world, and more than half of all adults use social media, this hardly comes as a surprise (Poushter 2016). The most widely used social media platform is Facebook, which currently has more than 2,3 billion users (Statista 2019). In the Czech Republic alone, which is the point of focus of this article, the internet is used by over 7,8 million of real users older than 10 years of age, representing 76,5\% of the population (NetMonitor 2018, Kucera 2017). More than 5,3 million people have an account on Facebook - far more than any other social network site - and over $77 \%$ of these users use Facebook daily (Huskova 2018; Focus 2017; Vaculík 2019).

The gradual increase in the professionalisation of political communication, which is apparent in the countries of Central and Eastern Europe, foreshadowed the quick and dramatic changes noticeable in the past decade towards more intensive, more strategic and more personalised conduct of political campaigns organised across new media platforms (see Cabada - Tomšič 2016, Negrine - Lilleker 2002, Gerodimos - Justinussen 2015: 114). Digitalisation of a 'permanent campaign' allowed political parties, as well as individual partisan and independent candidates, to reach out to loyal and volatile voters during the electoral cycle and restored the initial hopes that the Web would mediate dialogue - and therefore a more robust relationship - between citizens and their elected representatives (Kent - Taylor 1998). Whereas the sites of political parties were for a long time primarily used to provide basic information to visitors and to mobilise supporters of the party, with the emergence of social networks political communication lost the character of 'static campaign posters' (Enders Warnick 2008: 323). It can be called into question though to what degree online political communication is meaningful and constructive, and if it allows for the mobilisation of the wider electoral base (Gerodimos - Justinussen 2015: 115).

As Quinlan et al. (2017) state, political candidates are rational actors, whose goal is to maximise the amount of received votes in the elections (see, e.g. Aldrich 1995, Downs 1957). In the past years communicating online through new media platforms was integrated into the political campaigns of many political actors, as it allowed them to promote and publicise the campaign freely, as well as to interact with the broad public (Bronstein 2013). Although the dynamics of hybrid media systems influence political communication significantly (Chadwick 2013), political actors control the amount and quality of information, which they can produce daily without the need for negotiating and compromising with other actors, especially journalists and media networks. New media thus introduce one crucial advantage: they make it possible to communicate 
freely without any interventions from the traditional media. In this half-public and half-private environment, political actors can meet their voters personally in the online sphere (Gunn - Skogerbo 2013, Quinlan et al. 2018, Russmann Swensson 2017).

Although online communication with the electorate is an essential method for political subjects to promote their campaign and achieve an electoral victory, the degree to which candidates employ new media in their communication strategies depends to no small degree on the financial resources, personality and level of comfort with using social media. For partisan candidates, the party directive regarding communication strategy matters as well (Quinlan et al. 2017). During the electoral campaign, we observe that the main political leaders in developed democracies increase their number of daily posts. There is an increase in the personalisation of political communication while the number of posts addressing specific program priorities is decreased, and there is an apparent inclination towards the negative campaign. Across the board, the candidates then strive to present their communication as a personal and private dialogue with the social media users (Ceccobelli 2018: 14).

\section{Personalisation of electoral campaigns and the point of focus}

The main aim of this article is to continue the research focused on the topic of self-personalisation in the online environment and the impact of the self-personalisation style as a political tactic (see, e.g. Metz et al. 2019, McGregor et al. 2017, Gerodimos - Justinussen 2015, Small 2010). The theoretical concept of political personalisation focuses on the campaigns of individual politicians at the expense of political parties and institutions (Rahat - Schaefer 2007). From this perspective, personalisation is the process of the increased concentration of the publicised message of individual political candidates to raise the interestingness and media relevance of the message (Stromback 2008).

Individual actors as central figures of campaign communication share more personal and private posts, which are not always centred on their political program or party agenda (Vergeer et al. 2013: 4-6). The candidates often present themselves as regular people. They are citizens living among their electorate, and strive to make themselves relatable beyond the scope of their formal office (see e.g. Bene 2017, Gerodimos - Justinussen 2015, Manning et al. 2017, Ross Burger 2014), or as professionals who possess individual qualities and can bear professional responsibility for political activities and tasks (Hermans - Vergeer 2013, Kruikemeier 2014).

Van Aelst et al. (2012), in their article, define personalisation as a concept on two levels: individualisation and privatisation. If we adhere strictly to their definition, the communication of individual politicians in the online environment is always considered personalised communication, and thus the possibility of 
a closer examination of its nuances would be eliminated. On the other hand, Metz et al. (2013) build on the assumption that voters are strongly influenced by the personal style of political communication. The electorate increasingly bases their assessment of individual candidates on the information regarding specific candidates originating from their self-presentation on social media sites. As this view allows us to look closely into the way the individual politicians present themselves on the internet, this study follows this line of logic and further employs the definition of Van Santen and Van Zoonen (2010) who distinguish three separate dimensions of personalisation. In the professional dimension politicians communicate activities and qualities that are linked to their office; in the emotional dimension the actors put their personal feelings into the forefront of the message; and in the private dimension of personalisation they convey personal information about their private lives, not related to the political office they are running for (see Van Santen - Van Zoonen 2010 for details).

Although the definitions of personalisation in the scholarly research can differ, the academic public often points out the fact that social media stimulate and encourage the use of the personalised communication style in the campaign (Metz et al. 2019: 4). Social networks are oriented primarily on individual actors. They allow individual actors to bypass the mass media and traditional journalism and to quickly create their content to publish and share without the need for extensive technical, IT and PR investment. There is a strong foundation for the 'equalisation thesis' in the political communication research (see Ward et al., 2003, Gibson and McAllister 2014), ${ }^{2}$ suggesting that individuals - and especially independent candidates without a strong backer - can profit from employing new media strategies in their campaign. As the individualised messages, separated from political parties or movements, have more significant potential to be communicated on social media, the personalisation of the environment increases, as the candidates are in charge of their self-presentation and profiling on their social media accounts (Hermans - Vergeer 2013, Enli - Skogerbo 2013, McGregor et al. 2017). Based on these assumptions, the following text aims to explore the aspects of personalisation and communication strategy towards the electorate during the campaign conducted through Facebook in the elections for the Senate of the Parliament of the Czech Republic in October 2018. The candidates that ran for office in four electoral districts in which senators were chosen in the capital city of Prague are analysed.

2 On the other hand, it has been pointed out by many researchers, that indeed large political parties and subjects with enough financial founds and professional PR in place benefit from the internet communication, as their professional and technologically sophisticated communication come across as more compelling and interactive to the public, delivering better campaign results (Margolis - Resnick 2000, Hermans - Vergeer 2012). 
H1: Candidates who conducted an actively personalised campaign on Facebook were more successful in the elections than candidates who used the social media network in a sporadic and less personalised way.

\section{Research sample and method}

As mentioned above, Facebook is currently the most popular social media website, with more than 2,3 billion users worldwide and over 5,3 million users in the Czech Republic. In the last decade, Facebook had become a 'critical player' for sharing news, primarily due to the simplicity with which users can share, recommend and link important messages (Olmstead - Mitchell - Rosentiel 2011). Facebook gained a dominant role in the sphere of political communication among Czech media, as it connects political actors and candidates with the most significant number of users, as well as with journalists, essential people from the public domain, experts and opinion leaders. Whereas Facebook is used by about half of the total Czech population, Instagram has only 2,3 million users, and Twitter has 389 thousand users (Vaculík 2019).

The analysis presented in this article focuses on the campaign that took place before the Senate elections held in October 2018. This campaign then represents an important case of self-representation and personalisation on the most widely used social media site in the Czech Republic. This is because not only partisan candidates, but also individual candidates ran for office and thus employed different styles of communication, approaches to personalisation and involvement on the internet in their campaign communication strategies. Specifically, for a comprehensive analysis, the attention is aimed at the way Facebook was used by the candidates running for office in four districts in the capital city of Prague. $^{3}$ The 2018 elections were held in Prague voting districts 17, 20, 23 and 28, which correspond roughly with the areas of Prague 12, Prague 4, Prague 2 and Prague 8 respectively. The period covered by this analysis focuses on the end of the campaign, between 1 September, 2018 and 11 October, 2018. Thus, it covers both the start of the most active campaign efforts in September and the end of the campaign until the day before the first day of the second round of the two-round runoff elections. It is vital to mention that from 41 candidates that ran for the senator's office, only 27 candidates had an active Facebook account during this period. The accounts studied were the official accounts linked to the candidate's website. No supporter or group profiles, nor the profiles of the political parties represented by the candidates, were taken into consideration. In order to respect the inter- and intra-platform dissimilarities (see Mascheroni Mattoni 2013; Brunnerová - Charvát 2017 for details), only one social media

3 Every two years, a third of the Czech Senate is elected. The Czech Republic is divided into 81 single-member districts, which have no larger than $15 \%$ difference in number of citizens. 
platform (Facebook) was observed. Moreover, the attention was focused on the profiles of the candidates themselves and not on the different groups or individual profiles supporting them.

Freelon and Karpf (2015: 391) stated that research of hybrid media, such as social networks, calls for the employment of hybrid methods. With this in mind, the following analysis employs a broader spectrum of methods, which allows us to not only explore how the social media platform was utilized by the candidates in generic terms, but also to bring a more complex picture regarding how Facebook users reacted to the content of posts shared by the political actors. In order to achieve the abovementioned aims, the method of qualitative-oriented sentiment analysis of user messages is used (see Brunnerová 2018: 139-146 for details), which is then complemented by quantitative observation of the shared posts and reactions, as well as a content analysis focused on the candidates' posts themselves.

In the sentiment analysis, over 14 thousand user comments and reactions posted on the candidates' profiles were manually coded and analysed with the Zoomsphere platform. All reactions in which a positive, negative, neutral or ambivalent sentiment was present were included in the sample. Posts which did not include any sentiment (i.e. posts that did not have any original content of the person who posted the reaction or comment) were disregarded. These include, for example, URL links without commentary or posts solely tagging another user. During the analysis, the correctness, accuracy or factual content of the comments was also disregarded. For the content analysis of 1.071 posts that were shared by the 27 candidates who possessed an active Facebook account, 35 main topics and 31 subtopics were identified based on a preliminary review across the posts; for every post, all included topics were identified and coded. Subsequently, it was identified whether the topics included professional, emotional or personal characteristics of personalised communication. In the sample, visual posts (pictures as well as emoticons) were also considered if they represented the identifiable sentiment of the user.

\section{Quantitative aspects of user favour}

It needs to be pointed out right from the beginning that the number of fans or followers on Facebook does not present a figure that would give evidence of how much the users of Facebook like the individual candidates. ${ }^{4}$ From the logic of social media, it is reasonable to assume that many users will follow a wider

4 Although we also need to take into consideration that on Facebook both targeted advertising and the althorithm-effected reach of the post impacts how many users see the specific post or the candidate's profile, it can also be assumed that if the candidate has an interest in reaching out to Facebook users and establishing an active communication with voters in a selected district, they will also consider these effects and will take the necessary course of action to promote their profiles. 
number of candidates, both the ones they like, but also candidates they have a critical attitude towards. In particular, political professionals, scholars and journalists often follow a spectrum of candidates disregarding their personal preference. Nevertheless, the number of followers still provides valuable insight into the number of users the candidates can reach out to with their posts and campaign. It allows us to depict trends of development and provide a contextual framework for the following analysis. Especially in the time right before the elections, a rapid growth or decline in the number of followers can suggest the importance the broad public assigns to various candidates and gives evidence to what the 'starting line' for candidates was.

\section{Table 1: Number of Followers}

\begin{tabular}{|l|r|r|}
\cline { 2 - 3 } \multicolumn{1}{c|}{} & 1 September, 2018 & 11 October, 2018 \\
\hline Jiří Drahoš & 155869 & 155200 \\
\hline Marek Hilšer & 43059 & 43843 \\
\hline Pavel Fischer & 42671 & 42906 \\
\hline Hayato Okamura & 6801 & 7150 \\
\hline Vladimír Kratina & 5118 & 6412 \\
\hline Lubor Michálek & 4637 & 4798 \\
\hline Aleš Gerloch & 2713 & 2798 \\
\hline Ladislav Jakl & 1838 & 2134 \\
\hline Petr Hannig & 1494 & 1483 \\
\hline Benjamin Kuras & 1087 & 1482 \\
\hline Lukáš Wagenknecht & 748 & 1214 \\
\hline Miroslava Skovajsová & 774 & 1161 \\
\hline Martin Dvořák & 1180 & 1067 \\
\hline Eva Syková & 848 & 924 \\
\hline
\end{tabular}

\begin{tabular}{|l|r|r|}
\cline { 2 - 3 } \multicolumn{1}{c|}{} & 1 September, 2018 & 11 October, 2018 \\
\hline Ivan Gabal & 891 & 912 \\
\hline Eva Tylová & 647 & 692 \\
\hline Milan Golas & 597 & 675 \\
\hline Jiři Nouza & 608 & 651 \\
\hline Marta Semelová & 637 & 640 \\
\hline Pavel Dungl & 6 & 335 \\
\hline Roman Petrus & 285 & 289 \\
\hline Ivan Pilný & 248 & 281 \\
\hline František Dobšík & 144 & 238 \\
\hline Jiří Haramul & 6 & 90 \\
\hline Ivan David & 68 & 72 \\
\hline Roman Kerekeš & 14 & 49 \\
\hline Jiří Witzany & 3 & 7 \\
\hline
\end{tabular}

An important observation regarding the number of followers on Facebook is that the three candidates who contested in the preceding presidential elections entered the hot phase of the campaign with a significantly larger follower base and thus were from the beginning in a very uneven position compared to other contestants, not only in the scope of the social media presentation, but also in the overall visibility of their campaign due to a thought-through PR offensive. The followership of Jiř́ Drahoš was dramatically higher, but even Petr Hannig, who ended in the penultimate spot in the first round of the presidential race had more followers than most of the other Senate candidates in Prague. On the other hand, partisan candidates entered the Senate campaign without an established broad base of followers, signifying that developing a social media presence in a permanent way between elections is not a priority for many political parties. The only partisan candidate with a broader base of followers was Hayato Okamura. ${ }^{5}$ The difference between the followership of candidates was quite significant.

5 It needs to be acknowledged though, that partisan candidates could have used the social media profiles of their parties to communicate with their electorate. 
During the campaign Drahoš had more than 150 thousand followers and could address not only a large number of supporters, but also his critics.

Similarly, Marek Hilšer and Pavel Fischer entered the campaign with a previously established followership of around 40 thousand followers. On the other hand, the remaining candidates did not have over hundreds or a couple thousand followers. The fact that most of the candidates were not followed by a wide base of Facebook users though suggests that the candidates did not utilize the social media site in its full capacity and did not prioritize establishing themselves on it before and during the campaign. They did not capture the attention of users to the degree where they would start to follow the individual candidate in order to be able to read their posts regularly. Especially independent candidates, who before the elections stood aside from the main political scene, remained rather unknown figures for the voters in their electoral districts, also due to their low visibility online.

\section{Figure 1: PTAT Metric in the Observed Period}

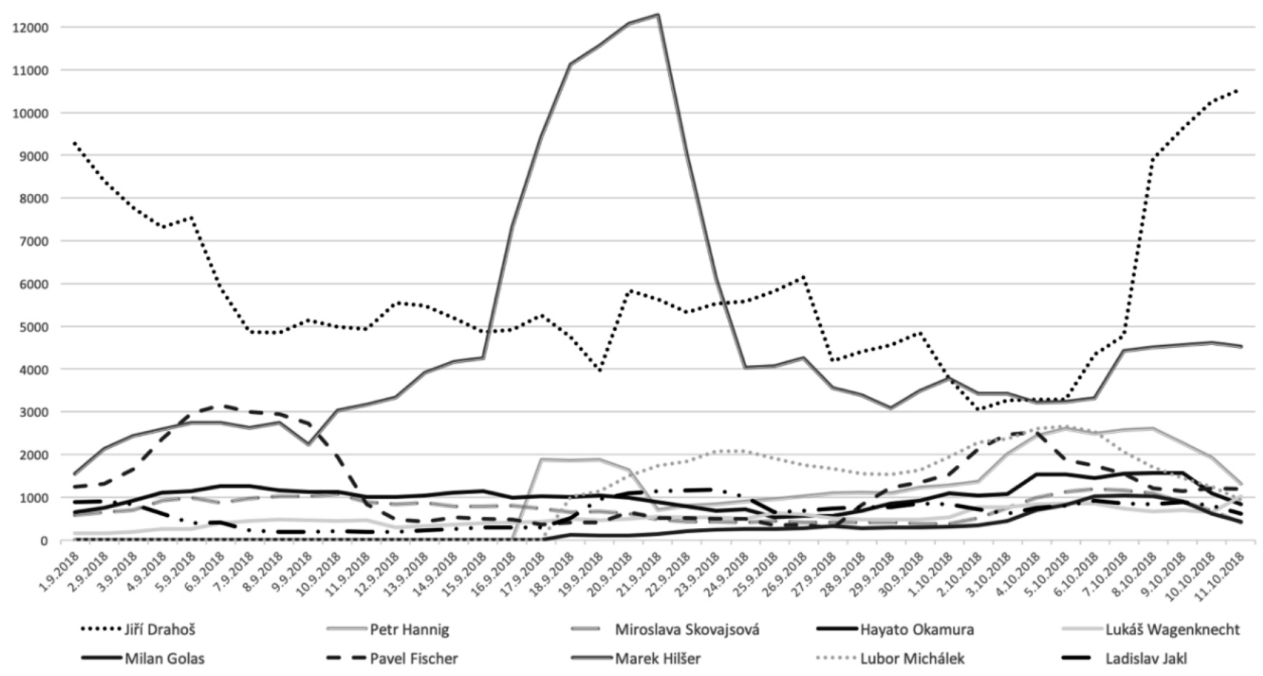

The PTAT indicator shows the level of engagement on the profiles of the candidates and points out how users reacted to the profile of an individual candidate, how many users shared the page, commented on it, gave it a 'like', became followers, tagged the page in their status etc. Although this metric does not show if the followers were positive or critical towards the candidate, it allows us to depict how the profile of the candidate stimulated and provoked a reaction or activity from Facebook users. As Drahoš, Hilšer and Fischer had a dramatically larger number of followers, it is not surprising that the PTAT indicator was also higher for them compared to other candidates in their respective districts. Not 
only were their profiles followed, but they encouraged and stimulated the users to actively participate in the discussion, to post their comments or share the profile and to draw even more attention to their campaign. The profile of Hilšer registered increased activity in connection to the discussion addressing the topic of immigration and refugees in the middle of September 2018. Contrarily, the profile of Drahoš became increasingly active during the first round of the elections and after they ended. It is not without interest that Lukáš Wagenknecht, although possessing a lower number of followers than other successful candidates, used both his profile and the official profile of his party to present himself to the electorate, and managed to positively accumulate user interest and increase the number of followers, as well as interactions on his profile.

On the other hand, the profiles of other candidates who entered the second round of the elections showed a very low degree of users' interest. Although the number of reactions on the profile of Eva Tylová increased during the last days of her campaign, compared to Fischer, who was her rival in the second round, the mobilisation of interest could not compete. Similarly, the other unsuccessful candidates from the second round were not able to mobilise their online supporters sufficiently on Facebook and spread the general knowledge of their candidacy, opinions or campaign activities to their potential voters.

\section{Table 2: Number of Shared Posts in the Observed Period}

\begin{tabular}{|l|r|}
\hline Hayato Okamura & 92 \\
\hline Benjamin Kuras & 86 \\
\hline Miroslava Skovajsová & 66 \\
\hline Ladislav Jakl & 60 \\
\hline Jiří Drahoš & 57 \\
\hline Lukáš Wagenknecht & 57 \\
\hline Aleš Gerloch & 54 \\
\hline Ivan Pilný & 53 \\
\hline Marek Hilšer & 51 \\
\hline Pavel Dungl & 43 \\
\hline Roman Kerekeš & 42 \\
\hline Roman Petrus & 41 \\
\hline František Dobšík & 39 \\
\hline
\end{tabular}

\begin{tabular}{|l|r|}
\hline Jiří Haramul & 38 \\
\hline Martin Dvořák & 36 \\
\hline Eva Tylová & 35 \\
\hline Libor Michálek senátor & 35 \\
\hline Jiří Nouza & 34 \\
\hline Vladimír Kratina & 31 \\
\hline Milan Golas & 28 \\
\hline Jiří Witzany do senátu & 24 \\
\hline MUDr. Ivan David & 24 \\
\hline Prof. Eva Syková & 19 \\
\hline Pavel Fischer & 18 \\
\hline Ivan Gabal & 10 \\
\hline Petr Hannig & 7 \\
\hline
\end{tabular}

A striking difference can be observed when it comes to the number of posts the candidates shared on Facebook. Whereas Okamura, Benjamin Kuras, Miroslava Skovajsová, Ladislav Jakl, Wagenknecht and Drahoš shared messages several times per day, especially as the first round of elections was getting closer, Hanning and Ivan Gabal only shared a handful of posts during the last month before the elections. Fischer, the winner in the electoral district of Prague 12, did not share a large number of messages either, especially compared to other successful candidates. Similar to Wagenknecht though, his posts gained the 
most 'likes' and positive reactions from users in his district, and due to the solid follower base, the posts were actively shared among the users. Contrary to for example the campaign taking place before the presidential elections in early 2018, where it did not go unnoticed that some of the candidates did not manage their Facebook communication on their own but instead used a team of PR specialists as well as volunteers to manage their social media accounts, it was a clear aim of the candidates in the Senate elections to evoke the feeling of authenticity and immediate communication with the public. Most of the candidates though did not involve themselves significantly in the discussion on their profiles, although, for example, Hilšer and Wagenknecht did react to the comments and replied to the messages on their profiles regularly.

\section{Topics of candidates' posts}

Interestingly, the most prominent topic of the candidates' posts on Facebook was the progress of the campaign itself. The candidates used their profile to relay the moments of the contact campaign to the users online. All candidates utilized Facebook to share moments from campaign events, inform their followers of planned meetings and upcoming events and share photos and videos from meetings with the voters. There was an apparent and noticeable emotional charge in these messages, which showed the most positive moments of the campaign and the encounters with Prague's inhabitants. The accentuation of the contact campaign was also noticeable in the personal contact with voters and the engagement of candidates in local events happening in the neighbourhoods of the electoral district they ran for. Communication on Facebook thus constituted an opportunity to relay the campaign on the ground to the wider public of voters present online, and it allowed the candidates to engage users who did not have the opportunity to meet them in the streets of Prague.

A very important topic of the campaign across the board was the personal lives of the candidates. Posts often addressed the life stories of the candidate, their family lives, but also their hobbies and pastime activities. Posts explaining - through text or video - why the candidate decided to run for the particular district were also prominent, as some of the candidates did not have their permanent address in that part of Prague and thus deemed it necessary to explain why they wanted to represent the inhabitants of that neighbourhood. Posts focusing on personal characteristics were crucial for less-known candidates, who utilised Facebook to present themselves to the public, acquaint the users with their previous professional career and accomplishments, but also to share their priorities and personal interests. For example, Skovajsová and Roman Kerekeš took the users of Facebook on a tour through their medical practices and their experiences as practising doctors. Ivan Pilný remarked on his success as a manager, but also as a minister of finance in the coalition government in 
2017. Aleš Gerloch presented his career as a lawyer and university faculty head, and Roman Petrus pointed out his work as mayor for the Social Democratic Party. Especially candidates who were not previously part of the political scene or were less well known from public life could thus strive to establish a personal relationship with Facebook users, as well as gain recurrent and plentiful comments, stating that a user will not vote for a particular candidate as they do not know (of) them.

In the area of political agendas, policies and program priorities, no single topic dominated the campaigns on the district level or in the overall Prague campaign. In the Senate campaign on Facebook topics were prevalent the voters could easily identify with. The candidates focused on the issues of environment and city greenery, the problematic housing market and traffic situation in the capital, improving the quality of education, as well as health and social care. This is well-illustrated in Drahoš's post from October 2nd in which he stated, accompanied by a photo from the contact campaign among voters in a Prague subway station, that 'in the city, we most importantly have to feel good. Nothing epitomizes this better than the well-known "safety of the home“. Quality schools, maintained streets, well-functioning transportation, playground [sic] for children. Even the most vulnerable of us will know that we will take care of them' (Drahoš 2018b). Accentuation of topics important for the voters in the electoral district was vital also in the posts of Wagenknecht, who stated in a post that a 'Senator should be in my opinion an advocate of the citizens of his electoral district. If elected, I will be the advocate and defender of local topics of citizens' (Wagenknecht 2018b).

On the other hand, among the peripheral topics, only sporadically were the issues of European integrations, migration or taxation discussed. Although these topics elicit an active response from many Facebook users, these reactions were often quite critical towards the candidate, no matter what the specific stance was they took towards the issue (see below). The topic of the European Union (EU) was very important in the campaign of Okamura, who declared that his program is 'democratic, pro-west and pro-European - with the emphasis on the freedom of the individual, but simultaneously on social cohesion and consideration among the people in our society' (Okamura 2018). Migration was thematised by Kuras, who said in a post 'Please become aware [...], a civilization catastrophe is rushing towards us. In a couple of months, illegal immigration will end because it will turn into "legal“ migration. The „Global Compact for Safe, Orderly and Regular Migration" will establish migration as a fundamental human right and the acceptance of migrants and taking care of them as an obligation of all European countries'. (Kuras 2018). Less frequently discussed topics were the issues of 'marriage for all' and adoption for same sex parents, addressed supportively by Skovajsová. Another less frequent topic was the protection of the Czech language, history and identity, which was thematised 
repeatedly by Gerloch, who aimed to protect the idea of the Czech nation and Czech language by amending the constitution to explicitly state that Czech is the official language, and to call the Czech Republic homeland of the Czech nation, making these features state-forming.

Most of the candidates focused their attention on the representation of two to three major topics, occasionally including complementary policies into their priorities. Most often the selection of represented topics was directly linked to the previous profession of the individual candidate, or their previous political engagement. In the posts linking their professional experience and the topics they wanted to represent, candidates running for the office of Senator pointed out their competence and expertise in the given field. Drahoš focused primarily on the issues of education and schooling, Tylová addressed the situation regarding housing in Prague and the environment, Dobšík and Petrus concentrated on traffic and transportation, whereas Pavel Dungl talked primarily about healthcare, similar to Kerekeš or Hilšer, who linked public health with social-security policies. Many candidates in the electorate districts thematised the issues of bureaucratic apparatus and digitalisation of administration and public service. These topics were prominent in the campaigns of Wagenknecht and Drahoš.

Besides sharing posts, candidates communicated their opinions and priorities on Facebook by sharing interviews with journalists, articles written about them and TV and radio appearances. Quite often, the candidates used a historical anniversary to present their own opinions and programmatic priorities. Videos of the candidates with supporters were very popular, and famous figures, celebrities, politicians and personal friends spoke on their behalf and about their qualities and expertise. It is not without interest that candidates very often encouraged the electorate to participate in the election and vote. Candidates even openly addressed the fact that 'likes are not votes' (Skovajsová 2018) and that 'showing fondness and support is nice, but if they do not transform into ballot paper in the ballot box, it means a single thing: your vote was forfeited, and you will not be heard' (Drahoš 2018c). The candidates across the districts thematised the issue of low election turnout in the Czech Republic, the role and importance of the Senate as well as the civic engagement in politics.

The presentation of individual candidates put a strong emphasis on the absence of political scandals, extensive professional expertise and experience, strong work ethic, as well as an understanding of the citizens in Prague's districts and a continuous effort to improve the lives of the electorate. Particularly for candidates who lacked extensive political experience, as in the case of Gabal or Skovajsová, pointing out that they are not linked to any political affairs or scandals was a handy benefit and spun their lack of political experience. It was evident that it was crucial for the candidates to present themselves in person and to convince voters with their personality, rather than their political program and specific policies they wanted to implement in the Senate. Drahoš and 
Hilšer often accentuated emotional and individualized personalisation in their messages. Drahoš often addressed his hobbies, as well as his student days, and Hilšer shared his activities with his family. Both candidates put a strong emotional charge on the messages addressing current events. On the other hand, Fischer often shared posts that related to the duties carried out by a senator, but he also communicated personal and emotionally charged messages. Wagenknecht and Dung, who competed against each other in the second round and whose duel for the mandate was the closest, both focused on professionally aimed posts, similarly to Tylová and Lubor Michálek, who did not succeed in the second round of the elections.

\section{Sentiment towards the successful candidates on Facebook}

\section{Figure 2: Sentiment towards Jiř́ Drahoš}

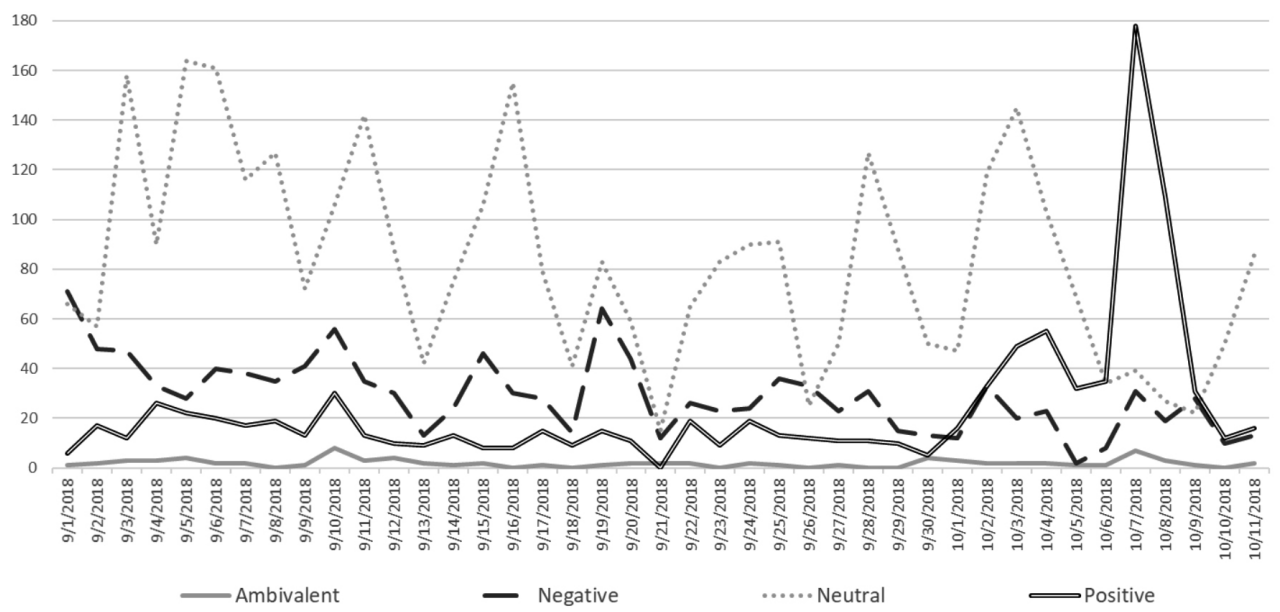

Drahoš was the only candidate in Prague (and one of the only two candidates republic-wise) who won in the first round of the elections by obtaining an absolute majority of votes - he attracted the vote of $52,65 \%$ of the electorate. His campaign was the most expensive out of all the non-partisan candidates. He spent over 1 million CZK on the campaign, with a significant portion of that amount being dedicated to PR and marketing (UDHPSH 2018). The campaign on Facebook reflected this, as it has been conducted de facto permanently since the presidential elections held at the beginning of 2018. The campaign was conducted through a combination of posts commemorating important historical events and anniversaries, addressing the essential programmatic topics and priorities, presenting official campaign visuals and, especially as the campaign culminated, focused on photos of the candidate with the public during informal 
meetings and campaign events. Recurrent emphasis on emotional and private aspects of the personalised campaign received mainly positive reactions on Facebook. In particular, posts in which Drahoš shared memories from meetings held in Prague 4 and from the contact campaign were often commented on by his supporters. Others that drew positive reactions were from the beer festival Pivofest and the beers that the candidate tasted and preferred. From the contact campaign in the subway stations, during which Drahoš discussed with voters what they would like to improve about politics in their district, or posts about Drahoš' time at the Technical University. These raised positive reactions from potential voters, as well as users who could not vote in Prague 4, but who were exposed to Drahoš' profile as he became increasingly visible in the internet environment. Similarly, the discussion regarding the topics that Drahoš thematised helped to increase the reach of the campaign. During the observed period, an active neutral discussion commenting on current political affairs was present in the comment section.

Negative sentiments towards Drahoš on Facebook were observed mainly during the elections. The levels of positive sentiment were constant and spiked dramatically before the first round of the election. Interest, which raised Drahoš profile, as well as the levels of positive sentiment, was several times greater than that of Eva Syková, who came second in the elections in Prague 4 with $13,06 \%$ of the vote. It needs to be pointed out that negative sentiment was also predominant on Syková's profile, and there was only a minimal positive reaction towards the candidate of the government party ANO.

Distinctively negative sentiment was present on Drahoš's profile under posts that communicated concrete program priorities and showed the candidate's opinion regarding current political topics. Whereas in the campaign before the presidential election Drahoš often pointed out his previous professional successes and his expertise, in September and October 2018 he thematised more historical anniversaries and topical events. These posts then attracted positive as well as adverse reactions from users. Where the support for the candidate was mostly generic, stating fondness and positive preferences, negative comments were mostly specific and concrete, evaluating opinions of Drahoš. However, as with the negative sentiment, the reactions often commented on the character or physical features of the candidate. Users mockingly noted the false glasses Drahoš wore, which was raised during the presidential elections, or the campaign event during which Drahoš skinned a rabbit. A significant wave of negative sentiment was brought by posts in which Drahoš commented on the current issue of migration, political development regarding immigration and the $\mathrm{Eu}-$ ropean Union. Similar to Hilšer, the most negative reaction was towards a post that combined the topic of Syrian orphan refugees with criticism of the prime minister Andrej Babiš, in which Drahoš stated 'That is enough! The discussion regarding children who experienced the loss of their parents, is completely 
distasteful [...] Mister Babiš, it is undignified when the prime minister of this country gathers political points on the trading with fear!' (Jiří Drahoš 2018a). Very often not only was the content of the post viewed negatively, but also the resolute form in which Drahoš communicated in these elections. Similar to the presidential campaign six months prior, critical users again stated that Drahoš lacked his own opinions. Drahoš's criticism of president Miloš Zeman was also met with negativity. Facebook users repeatedly noted that they felt like Drahoš was embittered and lacked sufficient political experience, or that he sought the political office for personal and financial gain, and that he was not connected to the district of Prague 4 as he does not have a permanent address there. Similar to Hilšer, Drahoš invested his time in pointing out that he was linked to the district and explained his motivation to represent voters of this neighbourhood. In the last days before the first round of the elections, positive sentiment started to rise dramatically, as more and more supporters came to the candidate's Facebook profile to show their support and write supportive messages. Especially positive reactions were then linked to the claim of competitor candidate Martin Dvořák, who said that Drahoš was behind a critical article, according to which Dvořák was supposed to keep money from the Club of Water Sports for himself (Blažek 2018).

\section{Figure 3: Sentiment towards Marek Hilšer}

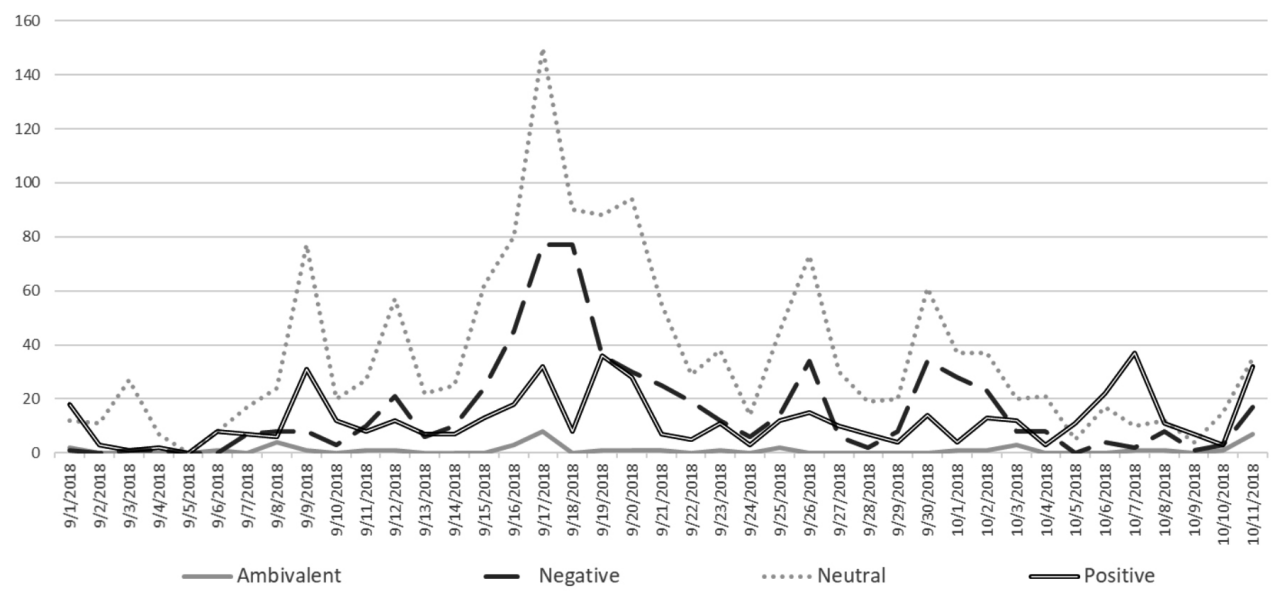

The campaign of Hilšer, who received $44,45 \%$ in the first round and won in the second round beating Michálek with $79,75 \%$ of the votes, was one of the cheapest campaigns among Prague's candidates, costing only a little over half a million CZK (UDHPSH 2018). Most of the funds - over 300 thousand CZK - were raised through a crowdfunding campaign on the HitHit platform. For financial contributions, Hilšer offered rewards in the form of button pins, 
shirts, homemade honey from his beehive and tickets for evening events, during which Hilšer spoke about his experience as a doctor in Kenya, or danced the tango. Both the campaign in the streets of Prague and the Facebook presentation were conducted in a light-hearted and relaxed style with a personalised campaign. For example, family photos with his wife and new-born baby doing everyday activities were included in posts, as well as pictures of Hilšer riding around his district of Prague 2 on a red moped and acting as a 'living billboard' (Hilšer 2018b).

Hilšer, who built his social media presence and his campaign in general on strong personal contact with voters, enjoyed positive sentiment from users throughout the entire period we studied. Nevertheless, especially during the second half of September and the beginning of October, negative sentiment towards the candidate prevailed, as Hilšer shared a series of posts that negatively commented on the current political situation and criticised Prime Minister Babiš. Active and often negative and even exasperated discussion, which sparked off of Hilšer's profile though raised the number of day-to-day interactions and significantly increased the reach of the campaign. Negative sentiment was often triggered by posts that had what the users perceived as an activistic campaign tone - the users pointed out to Hilšer that he was running for the Senate of the Parliament of the Czech Republic, not a local government. They further pointed out the powers and authorities of the senator, with the objection that as a Senator Hilšer would not be able to realise some of his priorities and they questioned how Hilšer wanted to fulfil his promises. The users also noted that for Hilšer, the presidential campaign was only a springboard to the Senate race. As in the case of Drahoš, it was criticised that Hilšer runs for office in Prague since his original place of residence was the city of Chomutov.

As mentioned above, reactions towards posts that addressed specific policy agendas and priorities of the candidate were both distinctively negative, and also highly positive. The largest increase of negative, and ambivalent, sentiment was raised by a post that was published by Hilšer in the middle of September, in which the candidate stated in connection with the acceptance of Syrian orphan refugees that the prime minister of the country is a 'heartless psychopath, who spreads his poisonous egoisms' (Hilšer 2018a). His criticism of the prime minister at the end of September and a post published in October, in which he spoke about the activities of the Czech Republic in NATO or the EU, were also perceived negatively. The fact that Hilšer remained in communication with his critics on his profile and actively participated in the discussion was regarded positively, as was his friendly conduct.

Positive comments, especially in the beginning of the observed period and in comparison with negatively oriented replies, were short and comprised of brief statements of support or agreement of a particular message of the candidate. The users were appreciative of Hilšer's congenial conduct, his pleasant 
appearance and especially the posts of him with his family and meetings with the citizens. Users who had the opportunity to 'catch' the candidate on his rides through Prague 2 often posted their pictures directly on Hilšer's Facebook profile and shared the positive impressions of the meeting with him. At the end of the campaign, a wave of positive feedback was brought by the Hilšer's criticism of his rival in the second round, Michálek, who right before the deciding round asked Hilšer to step down from the race. Michálek could benefit during his campaign from the fact that he occupied the post of Senator for this Prague district in the previous term and also from the support of the Czech Pirate Party for which he ran. During the whole campaign, his profile was less popular than Hilšer's, and his appeal to Hilšer, asking him not to continue with the campaign right before the second round dramatically increased the negative sentiment on his profile.

\section{Figure 4: Sentiment towards Pavel Fischer}

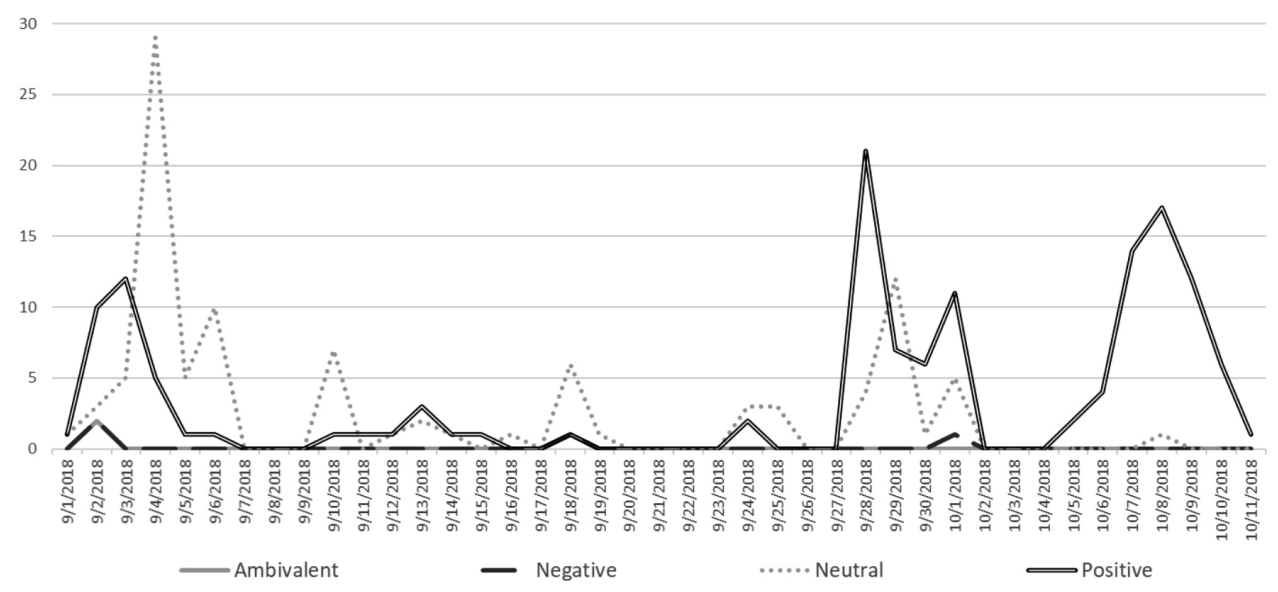

In Prague's $17^{\text {th }}$ electoral district Fischer ran for office and gained $49,98 \%$ of the vote in the first round and won the election in the second round with 78,07\% of the vote. Unlike Drahoš and Hilšer, Fischer focused his Facebook campaign mostly on sharing interviews, articles and TV appearances, as well as presenting his professional qualities and experience. As Fischer was competing for office in his place of residence, he did not have to justify his decision to run for his particular voting district. Although compared to the other winning candidates his communication was rather sparse, Fischer and his team were very active on his personal website, where the candidate regularly shared articles, invitations for campaign events, photos from meetings as well as personal stories about his past time activities and hobbies. While the profile on Facebook was less active, it still attracted significant attention of users, especially compared to Fischer's 
rival in the second round. On Tylová's profile, just a handful of users' reactions appeared during the observed period, and the only increase in interaction happened during the second round. These comments were mostly negative.

Fischer, similar to other winning candidates, shared his experiences from meetings that were conducted during the campaign or the events he attended. Feedback on his photos from a concert on Slovanský Island was very positive, as were photos from the Milada Horáková memorial reveal and the Moravian Saint Wenceslas Feast, which Fischer attended with his wife. Although Fisher was among the candidates with a lower amount of shared posts, due to the high number of followers and regular communication with users, his posts had a great outreach to the users of Facebook. Even though the activity on his profile was not as high compared to other successful candidates, when compared to other candidates in the $17^{\text {th }}$ electoral district in Prague Fischer's profile was among the most visited, most commented on and most shared ones.

Fischer's most positively received post was a short video in which the candidate sympathized with independent journalism and rejected attacking journalists (Fischer 2018a). Also proving popular was a video commemorating the holiday of Saint Wenceslas, in which Fischer stated that one of his priorities is the support of solidarity and justice in society (Fischer 2018b). Facebook users appreciated in Fischer's typically short commentaries, his pleasant demeanour and polite presence but they also commented on his experience in diplomatic service and that his opinions 'were reasonable'. The support and positive sentiment towards the candidate started to increase substantially in the period before the first and second rounds of the Senate elections, during which his profile was visited by any users who came to show their appreciation and wished the candidate a successful election result. Many users who showed their support were not citizens of Prague, but a wide public from the entire Czech Republic, who repeatedly said that they wished that Fischer would run in the next presidential elections. Negative sentiment towards Fischer was minimal. The post that attracted the most positive reactions also gathered the most negative reactions. It involved the defence of independent journalism and journalists in the beginning of September. Some users also negatively perceived Fischer's long engagement abroad.

Wagenknecht was the one candidate from the winners of Prague's Senate elections who was a member of a political party, the Czech Pirate Party. Wagenknecht proceeded to the second round with the lowest supremacy over his rival. In the first round, he received only $18,5 \%$ of the vote, whereas the second candidate, Dungl, got 15,29\%. The competition in the second round was the tightest from the four Prague districts. Wagenknecht won with 54,45\% of the vote. Although the popularity of his profile was not as strong when compared to other successful candidates, Wagenknecht benefited from the attention of more than 100 thousand users who followed the Facebook profile of the Pirate 


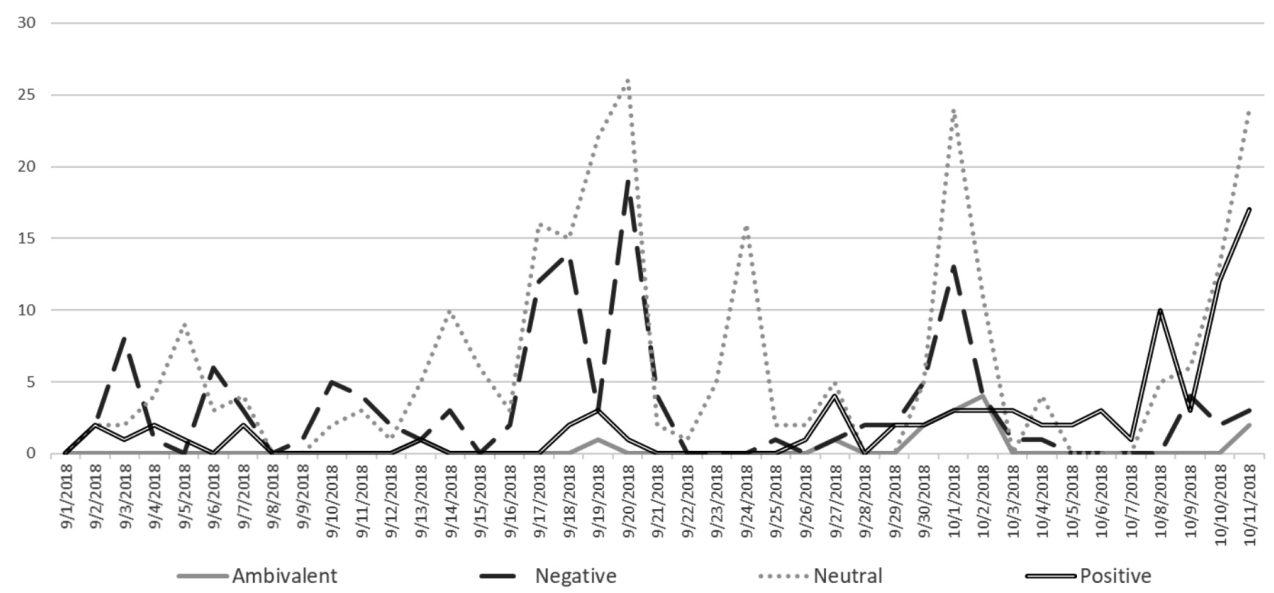

party, which throughout the campaign delivered information on the campaign and Wagenknecht's candidacy. The presentation of the candidate, who focused his campaign on the issue of corruption, consisted of sharing photos from meetings with the electorate and videos on Facebook that communicated his programmatic priorities. Wagenknecht also used comedy sketches, which outlined the priorities he wanted to address in the Senate. In comparison to Dungl's campaign, who competed against Wagenknecht in the second round, it was noticeable that during the whole observed period Wagenknecht attracted a larger number of positive comments, but also a lively discussion about current political issues and problems not directly related to the candidate's campaign. Not only the followership but also the activity on Dungl's profile was noticeably lower, and especially in the days before the first and the second round the number of negative reactions increased.

Wagenknecht approached his campaign in a light manner, employing humour and focused, similarly to Fischer, more on the professional topics rather than on emotional and private messages like Drahoš and Hilšer. His connection to a political party brought Wagenknecht more space in the context of the social site and raised the visibility of the campaign. However, his connection to the Czech Pirate Party was also a cause of many negative comments, in which users stated their negative feelings towards both the candidate and the party, as well as ambivalent comments, which supported Wagenknecht but were critical of his relationship with the Pirates. The perception of the candidate's employment with the Ministry of Finance during the period in which Andrej Babiš was the prime minister was also negative. Users noted that Wagenknecht did not become the deputy in the area of financial management and audit with the intention of 
'fighting against injustice', that he lacks expertise or that he 'collaborates with a state-security member and a liar' (Lukáš Wagenknecht 2018a). One of the most negative reactions was towards Wagenknecht's policy priorities and the criticism of Andrej Babiš in the middle of September 2018. It is not without interest that the candidate's position against corruption was usually perceived positively by users, but some users in the 17th district of Prague pointed out that there are more pressing issues in the district, like issues with parking, traffic or housing. A post in which Wagenknecht stated that the state service should be apolitical was received positively. Throughout the campaign on Facebook, users appreciated that the candidate 'says things how he sees them as correct' and is 'not afraid to express his opinions'. Especially positive was the sentiment towards the fact that the candidate regularly answered the comments and questions of the users and participated in the discussion on Facebook. Particularly at the end of the campaign, the positive sentiment prevailed over adverse reactions on the candidate's profile.

\section{Conclusion}

In the past decade, candidates for office in the Czech Republic have started to significantly increase their use of social media in political campaigns. Communication with the electorate through Web 2.0, the use of interactive websites, blogs and social media platforms in campaign strategies, have made it possible for political parties as well as individual politicians to share a wide range of content, from regularly posted messages, photos and videos, to surveys and requests for financial donations. Due to the communication in real-time, the easy access for the viewers as well as the possibility of immediate feedback and reactions from the electorate, and the possibilities for personalization, social networks allowed the candidates to take the campaign closer to the voters not only in personal contact but also through the permanent campaign conducted online.

Nevertheless, the use of new media for self-presentation and direct communication is only gradually becoming a more permanent feature of political campaigning in Central and Eastern Europe. Although many Czech politicians and political parties have become active on social media, a broad group of political actors employs online communication only sporadically in their campaign strategies, without using the full potential of the internet. This is also evident in the case of the Senate elections, which are the focus of this text. Out of the 41 candidates that ran for office in four districts in Prague, only 27 candidates had an active profile on Facebook a month before the elections, the most widely used social media platform in the Czech Republic.

This article aimed to thematise the self-personalisation in the online environment and the consequences of a self-personalised style as a campaign tactic. The goal was to examine the aspects of a personalisation and communication 
strategy towards the voters in the case of Facebook communication that took place directly before the elections to the Senate in the autumn of 2018, as these elections demonstrate how individual candidates running for office approach their presence on social media. The observed period covered the 'hot phase' of the campaign as well as its culmination; through both qualitative and quantitative methods, it was analysed, whether the candidates who lead an active and personalised campaign were more successful.

Jiří Drahoš, Marek Hilšer and Pavel Fischer started their campaigns more than a half year before the Senate elections when they ran for President of the Czech Republic, and at the beginning of the observed period had a significantly higher number of followers and interactions than other candidates. Not only Drahoš, who was followed by several times more users than any other candidate, but also Hilšer and Fischer, had the opportunity to address a broader spectrum of citizens through social media. Especially for non-partisan candidates, the reach of their profile played a key role. Politicians who could have become better known to the users from profiles of their political parties (as in the case of Lukáš Wagenknecht or Pavel Dungl), whose followers often reach in the hundreds of thousands, did not have to dedicate as much attention to their profiles. A low number of followers, as well as a low number of interactions and engagement, often not surpassing a handful or couple of tens of users, implies that active employment of social media platforms and the opportunities for personalisation and direct communication with the users that new media allows for is not a prominent and standard feature of campaign strategies in the Czech Republic, even in the elections to the second chamber of Parliament. It is not without interest that from the 14 candidates who did not have an active profile on Facebook during the observed period, only one candidate (Josef Nosek who in the electoral district of Prague 8 ran for the political movement For Prague) gained more than $5 \%$ of the votes. Altogether, six out of eight candidates whose number of interactions on Facebook did not surpass 1,000, gained less than $10 \%$ votes. Although we cannot gauge from interactions, activity or number of followers how the users spoke about candidates, nor what their preferences towards candidates were, if they commented on the candidates' profiles positively or negatively, for which reason they followed the profile or if they were entitled to vote in the district of the candidate, it is apparent that being able to reach a wide group of user public can greatly increase visibility of the campaign and disseminate awareness of the candidate's campaign. Active social media users are further able to communicate their perceptions of the candidates as opinion leaders to other, less active users or people who are not active on social media and thus enlarge the campaign's scope.

The candidates used Facebook to inform users and voters about upcoming events and opportunities to meet the candidate. The communication about the contact campaign itself presented the topic most often communicated by the 
candidates. The candidates regularly used Facebook to share their interviews, articles about their campaign or radio and TV appearances. From the content of the posts that the candidates shared, it was evident that most actors based their candidacy on two to three topics which they wanted to represent in the Senate. Most often, issues such as healthcare, education, housing or transportation were addressed, as well as the environment and limitation of bureaucracy. Candidates primarily communicated the intention of improving the lives of the citizens of the given Prague district in particular ways, rather than thematising topics connected to global politics or raising more controversial issues, such as the relationship with the EU, migration or taxation. These topics were only communicated on Facebook sporadically. Candidates focused instead on getting the users acquainted with the campaign activities, meetings with voters in the streets of Prague, as well as the presentation of their professional expertise and character qualities, or to familiarise the users with their family and personal lives, hobbies and pastime activities. The proportion of posts addressing personal topics and emotional responses of the candidates on the one hand, and messages addressing activities and qualities linked to the duties of the Senator's office on the other hand, differed greatly. In the campaigns of Drahoš, Hilšer and to a lesser degree Fischer, posts that thematised personal lives, opinions and impressions of the candidates were prominent. However, Wagenknecht and Dungl, whose competition in the second round was the closest, as well as the candidates who were not successful, Tylová, Michálek and other candidates, focused primarily on communicating the professional aspects and topics related to representing and holding the office of Senator.

Facebook users reacted very positively to posts that were personalised, in which candidates presented themselves as ordinary citizens, as well as towards messages relaying interesting moments from the contact campaign, especially in photographs. The comments of users suggested that positive reactions came primarily from users who were already decided on supporting that particular candidate. On the other hand, negative reactions were most often directed towards posts with a professional orientation, thematising current political affairs, and controversial political topics. In particular, posts expressing criticism of the prime minister Andrej Babiš or the president Miloš Zeman raised recurrent negative (but on the other hand, often simultaneously positive) sentiment from Facebook users. Active discussions on the profiles of candidates and a high number of users who participated in the debate in the comments, however, could contribute to improving the reach of the profile on the internet and disseminate the campaign to other users. Even if the reactions were adverse, the critical group usually did not represent the primary electorate that the candidate targeted. Facebook played an essential role in the effort of the candidates to introduce themselves to the voters and to familiarise them with their personality. It also allowed candidates to explain why they chose to run in a particular 
district, what connects them to that neighbourhood and to establish a closer, more personal relationship with users, whom the candidates were supposed to represent in the Senate. The willingness of candidates to participate in the discussion and to reply to users' questions was appreciated.

Overall, it can be observed that conducting an active, personalised and reactive campaign on Facebook, mainly if it was led by candidates who were previously known to the public (from previous elections or a different political function) and led the campaign in a more permanent manner, had its unquestionable importance in the elections to the Senate that were conducted in the Autumn of 2018 in Prague. Nevertheless, it is also apparent in correspondence to previous scholarly research, that in the context of the Czech Republic new media do not present a panacea that would change the course of the elections for candidates who lack funds and who don't have sufficient support. For candidates who had more financial resources, a higher number of followers, or who raised positive sentiment, the victory in the election was far from guaranteed. Leading a continuous campaign that allowed for establishing a personal connection between the candidate and the user was highly beneficial for successful candidates. It provided feedback for continuous adjustment of the electoral strategy and made it possible for the candidates to spread the word about their candidacy beyond their supporter's bubble towards more passive users of the internet and to the citizens who did not pay attention to new media. Thus it can be concluded that online personalised campaigns are an important tool in the campaign strategy for Czech political candidates and should therefore attract continuous attention of the scholarly public, who should address the use of Web 2.0 not only from the stance of political parties and major players, but also in regard to local elections and elections accentuating individual candidates, as the personalisation of politics taking place online is a predominant trend that in past decades reached the countries of Central and Eastern Europe as well.

\section{References}

Aldrich, John H., et al. (2016): Getting out the vote in the social media era: Are digital tools changing the extent, nature and impact of party contacting in elections? Party Politics 22 (2): 165-178.

Aldrich, John, H. (1996): Why Parties? The Origin and Transformation of Party Politics in America. Bibliovault OAI Repository, the University of Chicago Press.

Bellucci, Paol - Garzia, Diego - Lewis-Beck, Michael S. (2015): Issues and leaders as vote determinants: The case of Italy. Party Politics 21 (2): 272-283.

Bene, Marton (2017): Go viral on the Facebook! Interactions between candidates and followers on Facebook during the Hungarian general election campaign of 2014. Information, Communication \& Society 20 (4): 513-529. 
Blažek, Vojtěch (2018): „Kandidát ODS do Senátu čelí oznámení, že si nechával statisíce určené vodákům. ", Seznam zprávy (20 October): https://www.seznamzpravy.cz/clanek/kandidat-ods-do-senatu-celi-oznameni-ze-si-nechaval-statisice-urcene-vodakum-57106 (6 June 2019).

Blumler, Jay G. - Kavanagh, Dennis (1999): The Third Age of Political Communication: Influences and Features. Political Communication 16 (3): 209-230.

Bronstein, Jenny (2013): Like me! Analyzing the 2012 presi- dential candidates' Facebook pages. Online Information Review 37 (2): 173-192.

Brunnerová, Olga - Charvát, Jakub (2017): Metody výzkumu politické komunikace v nových médiích: Přehledová studie. Politické vedy 20 (3): 116-149.

Brunnerová, Olga (2018): Jak vzbudit emoce: analýza sentimentu vůči prezidentským kandidátům před prvním kolem volby na sociální sítí Facebook, in Just, Petr - Brunnerová, Olga - Charvát, Jakub, a kol. Dobývání Hradu: česká prezidentská volba 2018. 139-146, MUP \& Togga.

Cabada, Ladislav - Tomšič, Matevž (2016): The rise of person-based politics in the new democracies: The Czech Republic and Slovenia. Politics in Central Europe 12 (2): 29-50.

Ceccobelli, Diego (2018): Not every day is Election Day: a comparative analysis of eighteen election campaigns on Facebook. Journal of Information Technology \& Politics 15 (2): 122-141.

Chadwick, Andrew - Stromer-Galley, Jennifer (2016): Digital Media, Power, and Democracy in Parties and Election Campaigns: Party Decline or Party Renewal? The International Journal of Press/Politics 21 (3): 283-293.

Chadwick, Andrew (2013): The hybrid media system: Politics and power, Oxford University Press. ČT24 (2016): „Senát přetrval 20 let. Hlasy, že je zbytečný, ale znějí dodnes. “, ČT24 (26 August): available at https://ct24.ceskatelevize.cz/domaci/1888386-senat-pretrval-20-let-hlasy-ze-je-zbytecny-ale-zneji-dodnes (4 August, 2019).

Dang-Xuan, Linh, et al. (2013): An investigation of influentials and the role of sentiment in political communication on twitter during election periods. Information, Communication \& Society 16 (5): 795-825.

Downs, Anthony (1957): An Economic Theory of Political Action in a Democracy. Journal of Political Economy 65 (2): 135-150.

Drahoš, Jiř́ (2018a). Facebookový profil Jiřího Drahoše (19 October). Available at: https://www. facebook.com/drahosjiri/posts/888851801502517 (06 June, 2019).

Drahoš, Jiří (2018b): Facebookový profil Jiř́iho Drahoše (2 October). Available at: https://www. facebook.com/drahosjiri/posts/888851801502517 (06 June, 2019).

Drahoš, Jiř́ (2018c): Facebookový profil Jiřího Drahoše (5 October). Available at: https://www. facebook.com/drahosjiri/photos/a.464669970587371/898250563895974/?type=1 \& theater (06 June, 2019).

Endres, Danielle - Warnick, Barbara (2004): Text-based interactivity in candidate campaign websites: A case study from the 2002 Elections. - 68 (Summer): 322-342.

Enli, Gunn S. - Skogerb $\varnothing$, Eli (2013): Personalized Campaigns in Party-Centred Politics. Information, Communication \& Society 16 (5): 757-774. 
Fischer, Pavel (2018a): Facebookový profil Pavla Fischera (3 September): available at https:// www.facebook.com/watch/?v=688944508145675, (6 June 2018).

Fischer, Pavel (2018b): Facebookový profil Pavla Fischera (28 September): available at https:// www.facebook.com/watch/?v=48355417549603, (6 June 2018).

Focus (2017): „UŽIVATELÉ SOCIÁLNÍCH SÍTÍ V ČR“, Focus Marketing \& Social Media Research (21 February): available at https://www.focus-agency.cz/aktuality/uzivatele-socialnich-siti-v-cr (4 August, 2019).

Freelon, Deen - Karpf, David (2015): Of big birds and bayonets: hybrid Twitter interactivity in the 2012 Presidential debates. Information, Communication \& Society 18 (4): 390-406.

Gerodimos, Roman - Justinussen, Jakup (2015): Obama's 2012 Facebook Campaign: Political Communication in the Age of the Like Button. Journal of Information Technology \& Politics 12 (2): 113-132.

Grusell, Marie - Nord, Lars (2016): Setting the Trend or Changing the Game? Professionalization and Digitalization of Election Campaigns in Sweden. Journal of Political Marketing, published online 17 October 2016.

Gunn, Sara Enli - Skogerb $\varnothing$, Eli (2013): Personalized campaigns in party-centred politics. Information, Communication \& Society 16 (5): 757-774.

Hermans, Liesbeth - Vergeer, Maurice (2013): „Personalization in E-Campaigning: A Cross-National Comparison of Personalization Strategies Used on Candidate Websites of 17 Countries in EP Elections 2009. New Media \& Society 15 (1): 72-92.

Hilšer, Marek (2018): Facebookový profil Marka Hilšera (19 September): available at https:// www.facebook.com/MarekdoSenatu/photos/a.285093921858091/698779760489503/?type=3

Hilšer, Marek (2018): Facebookový profil Marka Hilšera (19 September): available at https:// www.facebook.com/MarekdoSenatu/photos/a.285093921858091/698779760489503/?ty pe=3 (5 Match 2019).

Hilšer, Marek (2018a): Facebookový profil Marka Hilšera (15 September): available at https:// www.facebook.com/marek.hilser (2 April 2019).

Hrdina, Matouš (2013): Technologie není apolitická: Poznámky ke studiu politické komunikace v nových médiích. Mediální studia 7 (3): 291-308.

Hušková, Lucie (2018): „Facebook sleduje denně 4,1 milionů Čechů.“ Newsfeed.cz (22 November): available at: https://newsfeed.cz/facebook-sleduje-denne-41 milionu-cechu/ (6 June, 2019).

Huskova, Lucie (2018): „Facebook v ČR hlásí přes 5,2 milionů uživatelů“, Newsfeed.cz (22 May): available at https://newsfeed.cz/facebook-v-cr-hlasi-pres-52 milionu-uzivatelu/ (4 August, 2019).

Kent, Michael L. - Taylor, Maureen (1998): Building dialogic relationships through the world wide web. Public Relations Review 24 (3): 321-334.

Kruikemeier, Sanne (2014): How political candidates use Twitter and the impact on votes. Computers in Human Behavior 34: 131-139

Kucera, Petr (2017): „Počet uživatelů internetu v Česku stoupá, stále jsme však pod evropským průměrem", iHned (27 March): available at https://byznys.ihned.cz/c1-65673310-pocet- 
-uzivatelu-internetu-v-cesku-stoupa-stale-jsme-vsak-pod-evropskym-prumerem (4 August, 2019).

Kuras, Benjamin (2018): Facebookový profil Benjamin Kuras (9 September): available at: https:// www.facebook.com/benjaminkuras2018/ (5 March 2019)

Larsson, Anders O. (2015): The EU Parliament on twitter e assessing the permanent online practices of parliamentarians. Journal of Information Technology \& Politics 12 (2): 149-166.

Manning, Nathan et al. (2017): Politicians, celebrities and social media: a case of informalisation?. Journal of Youth Studies 20 (2): 127-144.

Mascheroni, Giovanna - Mattoni, Alice (2013): Electoral Campaigning 2.0-The Case of Italian Regional Elections. Journal of Information Technology \& Politics 10 (2): 223-240,

McGregor, Shannon C. - Lawrence, Regina G. - Cardona, Arielle (2017): Personalization, gender, and social media: gubernatorial candidates' social media strategies. Information, Communication \& Society 20 (2): 264-283.

Metz, Manon - Kruikemeier, Sanne - Lecheler, Sophie (2019): Personalization of politics on Facebook: examining the content and effects of professional, emotional and private self-personalization. Information, Communication \& Society, Published online: 20 Feb 2019.

Negrine, Ralph - Lilleker, Darren G. (2002): The Professionalization of Political Communication: Continuities and Change in Media Practices. European Journal of Communication 17 (3): 305-323.

NetMonitor (2018): „Internetová populace ČR dosáhla v březnu nového maxima: 7,77 milionu reálných uživatelů", NetMonitor: Sdružení pro internetový rozvoj (19 April): available at http:// www.netmonitor.cz/internetova-populace-cr-dosahla-v-breznu-noveho-maxima-7-77 milionu-realnych-uzivatelu (4 August, 2019).

Okamura, Hayato (2018): Facebookový profil Hayato Okamury (7 September): available at https:// www.facebook.com/profile.php?id=100010877374543 (5 March 2019).

Olmstead, Kenny - Mitchell, Amy - Rosenstiel, Tom (2011): “Navigating News Online: here people go, how they get there and what lures them away". Pew Research Center's Project for Excellence in Journalism, 9 May. Available at: http://www.journalism.org/analysis_report/ navigating_news_online, (9 May 2011)

Poushter, Jacob (2016): Smartphone ownership and internet usage continues to climb in emerging economies. Pew Research Centre: available at http://www.pewglobal.org (6 June 2018).

Quinlan, Stephen et al. (2018): 'Show me the money and the party!' - variation in Facebook and Twitter adoption by politicians. Information, Communication \& Society 21 (8): 1031-1049.

Rainie, Lee - Smith, Aaron (2012): Social networking sites and politics Pew Research Centre: available at http://www.pewglobal.org (6 June 2018).

Rahat, Gideon - Sheafer, Tamir (2007): The Personalization(s) of Politics: Israel, 1949-2003. Political Communication 24 (1): 65-80.

Ross, Karen - Bürger, Tobias (2014): Face to face(book). Political Science, 66:1, 46-62.

Russmann, Uta - Swensson, Jakob (2017): Introduction to Visual Communication in the Age of Social Media: Conceptual, Theoretical and Methodological Challenges. Me- 
dia and Communication 5 (4): 1-5. Skovajsová, Miroslava (2018): Facebookový profil Miroslavy Skovajsové (5 October): available at https://www.facebook.com/miroslava. skovajsova/posts/1918575448223739?comment_id=1918720424875908 \& reply_comment_ id=1918786698202614 \& comment_tracking=\%7 B\%22tn \%22\%3 A \%22R2\%22\%7D (4 August 2019).

Small, Tamara A. (2011): WHAT THE HASHTAG? Information, Communication \& Society 14 (6): 872-895,

Statista (2019). Most popular social networks worldwide as of April 2019, ranked by number of active users (in millions): available at https://www.statista.com/statistics/272014/global-social-networks-ranked-by-number-of-users/ (6 June 2019).

Strömbäck, Jesper (2008): Four Phases of Mediatization: An Analysis of the Mediatization of Politics. International Journal of Press-politics 13: 228-246.

Sweetser, Kaye D. - Lariscy, Ruthann W. (2008): Candidates Make Good Friends: An Analysis of Candidates' Uses of Facebook. International Journal of Strategic Communication 2 (3): 175-198.

Towner, Terri L. - Duolio, David A. (2011): An experiment of campaign effects during the YouTube election. New Media \& Society 13 (4): 626-644.

UDHPSH (2018): Řádné volby do Senátu 2018: available at https://www.udhpsh.cz/radne-volby-do-senatu-2018/ (6 June 2019).

Vaculík, Přemysl (2019): „Sociální sítě v Česku, využívá je 5,7 milionu obyvatel“, Dotekomanie. cz (21 February): available at https://dotekomanie.cz/2019/02/socialni-site-v-cesku-vyuziva-je-57 milionu-obyvatel/ (4 August, 2019).

Van Aelst, Peter et al. (2012): The personalization of mediated political communication: A review of concepts, operationalizations and key findings. Journalism 13(2): 203-220.

Van Santen, Rosa - Van Zoonen, Liesbet (2010): The Personal In Political Television Biographies. Biography 33 (1): 46-67.

Vergeer, Maurice - Franses, Philip H. (2016): Live audience responses to live televised election debates: time series analysis of issue salience and party salience on audience behaviour. Information, Communication \& Society 19 (10): 1390-1410.

Vergeer, Maurice - Hermans, Lisbeth (2013): Campaigning on Twitter: Microblogging and Online Social Networking as Campaign Tools in the 2010 General Elections in the Netherlands. Journal of Computer-Mediated Communication 18 (4): 399-419.

Vochocová, Lenka - Štětka, Václav - Mazák, Jaromír (2016). Good girls don't comment on politics? Gendered character of online political participation in the Czech Republic. Information, Communication \& Society 19 (10): 1321-1339.

Vochocová, Lenka - Švelch, Jaroslav (2015): Sociální média jako nová výzva pro výzkum politické participace. Sociologický časopis / Czech Sociological Review 51 (1): 65-88.

Wagenknecht, Lukáš (2018): Facebookový profil Lukáše Wagenknechta (12 September): available at https://www.facebook.com/WagenknechtLuk/photos/a.302731203253443/9968658571733 04/?type=3 \& _tn__=-R (6 May 2019). 
Wagenknecht, Lukáš (2018b): Facebookový profil Lukáše Wagenknechta (2 October): available at https://www.facebook.com/WagenknechtLuk/photos/a.302731203253443/996865857173 304/?type=3 \& _tn__=-R (6 June 2019).

Ward, Stepehne - Lusoli, W. (2005): Logging On or Switching Off? The Public and the Internet at the 2005 General Election, in Coleman, S. - Ward, S. (eds), Spinning the Web. London: Hansard Society, 13-21.

Olga Brunnerová is a doctoral candidate at the Department of Humanities and Political Science, Metropolitan University Prague. In her research, she focuses on new political parties, their electoral success and process of theirinstitutionalisation, especially in the area of the EU. She also deals with the topic of online political communication and electoral campaighns happening online through new media platforms. 